\title{
Association of central obesity and high body mass index with function and cognition in older adults
}

\author{
Reshma Aziz Merchant ${ }^{1} 1,2$, Michael Wong Wai Kit ${ }^{2}$, Jia Yi Lim² and John E Morley ${ }^{3}$ \\ ${ }^{1}$ Division of Geriatric Medicine, Department of Medicine, National University Hospital, Singapore, Singapore \\ 2Department of Medicine, Yong Loo Lin School of Medicine, National University of Singapore, Singapore, Singapore \\ ${ }^{3}$ Division of Geriatric Medicine, Saint Louis University School of Medicine, St Louis, Missouri, USA
}

Correspondence should be addressed to R A Merchant: reshmaa@nuhs.edu.sg

\begin{abstract}
Objective: To investigate the association of normal BMI with central obesity (CO), high $\mathrm{BMI}$ with $\mathrm{CO}$, high $\mathrm{BMI}$ without $\mathrm{CO}$, and normal $\mathrm{BMI}$ without $\mathrm{CO}$, with function and cognition in older adults.

Methods: Cross-sectional study involving 754 participants $\geq 65$ years. Data collected include demographics, cognition, and physical measurements.

Results: Females had a higher prevalence of high BMI with $\mathrm{CO}$ and a lower prevalence of high BMI without CO than males ( $61.0 \%$ vs $44.6 \%$ and $4.6 \%$ vs $15.0 \%$, respectively). Within gender, CO groups, regardless of BMI, had lower mini-mental state examination (MMSE), handgrip strength (HGS), and longer timed-up-and-go (TUG) scores. Overall, the high BMI without $\mathrm{CO}$ group had the highest MMSE scores, HGS, and shortest TUG. Amongst males, HGS was significantly lower in the normal BMI with CO group $(\mathrm{B}-3.28,95 \% \mathrm{Cl}-6.32$ to $-0.23, P=0.04)$. CO, regardless of normal/high $\mathrm{BMI}$, had significantly longer TUG time (B $2.65,95 \% \mathrm{Cl} 0.45$ to $4.84, P=0.02 ; \mathrm{B} 1.07,95 \% \mathrm{Cl} 0.25$ to $1.88, P=0.01$, respectively) than normal BMI without CO group. CO was associated with lower MMSE scores in both genders but significant only in males with normal $\mathrm{BMI}$ and $\mathrm{CO}(\mathrm{B}-1.60,95 \% \mathrm{Cl}-3.15$ to $-0.06, P=0.04)$.

Conclusion: CO may be a better predictor of obesity and adverse outcomes in older adults. High BMI without CO was associated with better outcomes especially in males but require further validation. Prospective longitudinal studies are needed to ascertain the impact of $\mathrm{BMI}$ and/or CO on function, cognition, mortality, and gender differences.
\end{abstract}

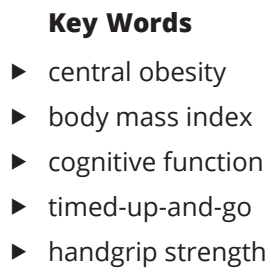

Endocrine Connections (2021) 10, 909-917

\section{Introduction}

Worldwide, the prevalence of obese and overweight adults continue to increase, affecting at least one in three men and women (1). Both are known to be independently associated with adverse outcomes such as reduced life expectancy, mortality, disability, poor quality of life, increased healthcare utilisation, and cardio-metabolic diseases such as diabetes and ischaemic heart disease $(2,3)$. While it is known that many obese individuals will develop cardio-metabolic health problems, there is a proportion of adults who remain free of diseases and are described to have metabolically healthy obesity (MHO).

BMI is often used as a measure of obesity in daily practice but should be interpreted with caution as it may be a poor indicator of fat distribution, especially in older adults. High BMI is associated with better survival and cognition in older adults $(4,5,6)$. Waist circumference (WC) reflects central obesity (CO), which is a risk factor for adverse outcomes including mortality independent of BMI 
and may be a better measure of obesity (7). The prevalence of $\mathrm{CO}$ continues to increase worldwide outpacing BMI, and by 2030 , the prevalence is projected to be $55.6 \%$ in men and $80.0 \%$ in women in the US $(8,9)$. Many studies have shown a 'U-shaped' curve for the relationship of BMI and mortality, and linear relationship between WC and mortality (10). Mortality rates in older obese adults were found to be lower than young obese adults (11). Highintensity interval training and aerobic exercises at least three times a week have shown to be effective in reducing visceral adipose tissue (12).

There are different impacts of high BMI and CO on physical function and cognition in the young and old (13). There is still an ongoing debate on the usefulness of measuring BMI as an indicator of obesity, and the cutoff for BMI in older adults. This study aims to examine the demographic factors and investigate the association of normal BMI with $\mathrm{CO}$, high $\mathrm{BMI}$ with $\mathrm{CO}$, high $\mathrm{BMI}$ without $\mathrm{CO}$, and normal BMI without $\mathrm{CO}$ with function and cognition in older adults.

\section{Methods}

The study population is a subgroup of the Healthy Older People Everyday (HOPE) cohort, which was part of the Singapore Population Health Studies - Community Health Study, conducted between April 2015 and August 2016 (14). The initial HOPE study was a cross-sectional and nationally representable cohort of 1051 older adults $\geq 65$ years old, recruited from a defined geographical area in the Northwest of Singapore. Only 754 participants with available measurements on waist circumference (WC) and BMI were included in the current analysis. Further details on recruitment, interview questionnaire, physical and cognitive assessment were elaborated in prior published studies $(14,15)$.

Interview questionnaires consisting of demographics, education level, chronic diseases, medications, falls, activities and instrumental activities of daily living, cognition, frailty, and perceived health were collected. It was administered by trained research staff and relied on selfreported data. Multimorbidity was defined by the presence of $\geq 2$ or more chronic illnesses while polypharmacy was defined by $\geq 5$ prescribed medications daily. Nutritional risk was assessed using the 3-min nutritional screening (3-MinNS) tool (16). Physically active was defined based on WHO recommendations of doing at least $150 \mathrm{~min}$ of moderate intensity or 75 min of vigorous intensity aerobic physical activity per week (17). Activities of daily living
(ADL) and instrumental activities of daily living (IADL) were evaluated using the Barthel Index and Lawton's IADL scale, respectively $(18,19)$. Cognition was assessed using the mini-mental state examination (MMSE) (20). Frailty was assessed using the 5-item FRAIL scale (fatigue, resistance, ambulation, illness, and loss of weight) which has been validated in many countries $(14,21)$. Perceived general health was measured using the EuroQol Visual Analogue Scale (22).

Participants were invited for physical assessment which consisted of height, weight, WC, timed-up-and-go (TUG) test (23), and hand grip strength (HGS). WC was measured midpoint between the last rib and iliac crest. The HGS was measured three times in each hand using a digital dynamometer (A5401, Takei Scientific Instruments Co., Ltd., Japan), and the maximum grip strength of the dominant hand was included in the analysis. Relative HGS was defined as the maximum grip strength of dominant hand over body weight (15).

According to WHO recommendations for Asians (24), the cut-off for normal BMI was $23.0 \mathrm{~kg} / \mathrm{m}^{2}$ and any value above this was regarded as high BMI. CO was defined by WC $\geq 90 \mathrm{~cm}$ for men and $\geq 80 \mathrm{~cm}$ for women according to International Diabetes Federation recommendations for Asians (25).

The research study complies with the Declaration of Helsinki's ethical principles. All procedures and purposes of the study were explained, and written consent was obtained from all recruited participants. The study protocol was approved by the National Healthcare Group (NHG), Domain-Specific Review Board (DSRB), Singapore.

\section{Statistical analysis}

The dataset was analysed using IBM SPSS Version 26.0. Categorical variables were presented as frequencies (\%), while continuous variables were stated as means \pm S.D. Chi-squared test, with Bonferroni correction, and oneway ANOVA, with Tukey's test, were used to determine significant differences between independent groups for categorical and continuous variables, respectively.

Sub-group analyses were carried out for both genders. Univariate and multivariate linear regression models were used to evaluate mean differences between BMI groups, with and without CO, on HGS, relative HGS, TUG, and MMSE. Normal BMI without CO was set as the reference group. The mean differences between the groups and the reference were reflected as B-coefficients with 95\% CIs included in all models. The multivariate models were adjusted for age, education, height, physical activity, and

This work is licensed under a Creative Commons Attribution-NonCommercial-NoDerivatives 4.0 Internationad ticense.ifica.com at 04/26/2023 08:20:23AM 
hypertension. Statistical significance was determined as $P<0.05$.

\section{Results}

Our study involved 754 community-dwelling older adults $\geq 65$ years old, mean age $70.8 \pm 5.1$ years, mean education $6.3 \pm 4.4$ years, $54.8 \%$ female, and $82.2 \%$ of Chinese ethnicity. As seen in Table 1, 53.6\% $(n=404)$ had high BMI with $\mathrm{CO}, 30.4 \%(n=229)$ had normal BMI without $\mathrm{CO}$, 9.3\% $(n=70)$ had high $\mathrm{BMI}$ without $\mathrm{CO}$, and $6.8 \%(n=51)$ had normal BMI with CO. Obesity prevalence defined by WC was $60.4 \%$ and BMI $62.9 \%$.

There was a higher prevalence of high BMI with $\mathrm{CO}$ amongst females compared with males, $61.0 \%$ and $44.6 \%$, respectively. Amongst the male, $37.0 \%$ belonged to the normal BMI without CO group compared with $24.9 \%$ females. Almost one in three of the Chinese ethnic group belonged to the normal BMI without CO group, compared to one in five Indian and one in seven of the Malay ethnic groups.

The high BMI with CO group had more significant associations with other health indices than the normal

Table 1 Characteristics of participants.

\begin{tabular}{|c|c|c|c|c|c|c|}
\hline \multirow[b]{2}{*}{ Variable } & \multirow[b]{2}{*}{$\begin{array}{c}\text { All, } \boldsymbol{n}=\mathbf{7 5 4} \\
\quad(100 \%)\end{array}$} & \multicolumn{2}{|c|}{ Normal BMI } & \multicolumn{2}{|c|}{ High BMI } & \multirow[b]{2}{*}{$P$ value } \\
\hline & & $\begin{array}{c}\text { No central obesity, } \\
n=229(30.4 \%) \text { (normal } \\
\text { BMI without CO) } \\
\end{array}$ & $\begin{array}{c}\text { Central obesity, } \\
n=51(6.8 \%) \text { (normal } \\
\text { BMI with CO) } \\
\end{array}$ & $\begin{array}{c}\text { No central obesity, } \\
n=70(9.3 \%) \\
\text { (high BMI without CO) } \\
\end{array}$ & $\begin{array}{c}\text { Central obesity, } \\
n=404 \text { (53.6\%) } \\
\text { (high BMI with CO) }\end{array}$ & \\
\hline Age, mean & $70.8 \pm 5.1$ & $71.1 \pm 5.3$ & $71.3 \pm 4.9$ & $70.2 \pm 4.8$ & $70.6 \pm 5.0$ & 0.37 \\
\hline Gendera & & & & & & $<0.01$ \\
\hline Male & $341(100.0)$ & $126(37.0 \%)$ & $12(3.5 \%)$ & $51(15.0 \%)$ & $152(44.6 \%)$ & \\
\hline Female & $413(100.0)$ & $103(24.9 \%)$ & $39(9.4 \%)$ & $19(4.6 \%)$ & $252(61.0 \%)$ & \\
\hline Ethnicity ${ }^{a}$ & & & & & & $<0.01$ \\
\hline Chinese & $620(100.0)$ & $204(32.9)^{A, C}$ & $49(7.9)^{\mathrm{B}, \mathrm{D}}$ & $58(9.4)$ & $309(49.8)^{A, B, C, D}$ & \\
\hline Malay & 43 (100.0) & $6(14.0)^{A}$ & $1(2.3)$ & $4(9.3)$ & $32(74.4)^{A}$ & \\
\hline Indian & $46(100.0)$ & $10(21.7)$ & $1(2.2)$ & $4(8.7)$ & $31(67.4)$ & \\
\hline Others & $45(100.0)$ & $9(20.0)$ & $0(0.0)$ & $4(8.9)$ & $32(71.1)$ & \\
\hline Education (years), mean & $6.3 \pm 4.4$ & $6.8 \pm 4.3^{\mathrm{A}}$ & $5.7 \pm 4.4$ & $7.3 \pm 4.5$ & $5.9 \pm 4.4^{A}$ & 0.02 \\
\hline Hypertension & $563(74.7)$ & $137(59.8)^{A, ~ B}$ & $36(70.6)$ & $58(82.9)^{A}$ & $332(82.2)^{\mathrm{B}}$ & $<0.01$ \\
\hline Hyperlipidaemiab & $429(56.9)$ & $107(46.7)^{\mathrm{A}}$ & $33(64.7)$ & $43(61.4)$ & $246(60.9)^{A}$ & 0.02 \\
\hline Diabetes & $231(30.6)$ & $47(20.5)^{\mathrm{A}}$ & $15(29.4)$ & $17(24.3)$ & $152(37.6)^{A}$ & $<0.01$ \\
\hline Stroke & $23(3.1)$ & $5(2.2)$ & $0(0.0)$ & $1(1.4)$ & $17(4.2)$ & 0.16 \\
\hline Heart attack ${ }^{d}$ & $37(4.9)$ & $10(4.4)$ & $3(5.9)$ & $4(5.7)$ & $20(5.0)$ & 0.89 \\
\hline Multimorbidity & $522(69.2)$ & $130(56.8)^{A}$ & $33(64.7)$ & $47(67.1)$ & $312(77.2)^{A}$ & $<0.01$ \\
\hline Polypharmacy & $103(13.7)$ & $25(10.9)$ & $10(19.6)$ & $5(7.1)$ & $63(15.6)$ & 0.08 \\
\hline Frailty status & & & & & & 0.27 \\
\hline Robust & $438(58.1)$ & $141(61.6)$ & $29(56.9)$ & $46(65.7)$ & $222(55.0)$ & \\
\hline Pre-frail & $274(36.3)$ & $80(34.9)$ & $17(33.3)$ & $21(30.0)$ & $156(38.6)$ & \\
\hline Frail & $42(5.6)$ & $8(3.5)$ & $5(9.8)$ & $3(4.3)$ & $26(6.4)$ & \\
\hline $\begin{array}{l}\text { Nutritional risk } \\
(3-\text { MinNS } \geq 3)\end{array}$ & $22(2.9)$ & $13(5.7)^{\mathrm{A}, \mathrm{B}}$ & $1(2.0)$ & $0(0.0)^{\mathrm{A}}$ & $8(2.0)^{B}$ & 0.02 \\
\hline $\begin{array}{l}\text { At least one ADL } \\
\text { impairment }\end{array}$ & $128(17.0)$ & $33(14.4)$ & $9(17.6)$ & $10(14.3)$ & $76(18.8)$ & 0.49 \\
\hline $\begin{array}{l}\text { At least one IADL } \\
\text { impairment }\end{array}$ & $292(38.7)$ & $93(40.6)$ & $16(31.4)$ & $25(35.7)$ & $158(39.1)$ & 0.62 \\
\hline Falls ( $\geq 1$ in past year) & $92(12.2)$ & $23(10.0)$ & $8(15.7)$ & $6(8.6)$ & $55(13.6)$ & 0.36 \\
\hline Physically active & $127(16.8)$ & $52(22.7)^{\mathrm{A}}$ & 7 (13.7) & $13(18.6)$ & $55(13.6)^{A}$ & 0.03 \\
\hline MMSE score, mean & $27.0 \pm 3.0$ & $27.4 \pm 2.9^{A}$ & $26.6 \pm 3.6$ & $27.5 \pm 3.0$ & $26.7 \pm 3.0^{\mathrm{A}}$ & 0.02 \\
\hline $\begin{array}{l}\text { Perceived health } \\
\text { (EQ-VAS), score }\end{array}$ & $80.7 \pm 14.5$ & $79.2 \pm 14.9$ & $80.6 \pm 12.6$ & $82.6 \pm 13.2$ & $81.2 \pm 14.7$ & 0.27 \\
\hline Grip strength $(\mathrm{kg})$, mean & $22.5 \pm 6.8$ & $23.1 \pm 6.8^{A, B}$ & $19.9 \pm 5.8^{A, C}$ & $26.5 \pm 6.8^{B, C, D}$ & $21.8 \pm 6.7^{D}$ & $<0.01$ \\
\hline $\begin{array}{l}\text { Relative grip strength } \\
\text { (kg), mean }\end{array}$ & $0.37 \pm 0.11$ & $0.44 \pm 0.10^{A, B}$ & $0.36 \pm 0.09^{A, C}$ & $0.43 \pm 0.09 \mathrm{C}, \mathrm{D}$ & $0.32 \pm 0.08^{B, D}$ & $<0.01$ \\
\hline TUG (s), mean & $11.3 \pm 4.0$ & $10.7 \pm 4.6^{A}$ & $11.1 \pm 3.4$ & $10.4 \pm 2.9^{B}$ & $11.8 \pm 3.8^{A, B}$ & $<0.01$ \\
\hline
\end{tabular}

Bold indicates significance; Values are $n(\%)$, otherwise mean \pm S.D.

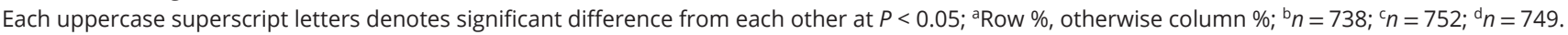
3-MinNS, 3-min nutrition screening; ADL, activities of daily living; CO, central obesity; EQ-VAS, EuroQol visual analogue scale; IADL, instrumental activities of daily living; MMSE, mini Mental state examination; TUG, timed up and go.

https://ec.bioscientifica.com https://doi.org/10.1530/EC-21-0223 (c) 2021 The authors Published by Bioscientifica Ltd

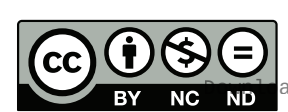

This work is licensed under a Creative Commons Attribution-NonCommercial-NoDerivatives 4.0 International License.ifica com at $04 / 26 / 2023 \quad 08: 20: 23 A M$ 
BMI without $\mathrm{CO}$ group. There was a significantly higher prevalence of hypertension (82.2\% vs $59.8 \%)$ and diabetes (37.6\% vs $20.5 \%$ ) in the high BMI with CO group compared with the normal BMI without CO group. In the subgroup analysis (Supplementary Table 1, see section on supplementary data given at the end of this article), diabetes prevalence remained significant only in females. There was a significantly higher prevalence of multimorbidity in the high BMI with CO compared with normal BMI without CO; $77.2 \%$ and $56.8 \%$, respectively.

Amongst the normal BMI without CO group, $22.7 \%$ were physically active compared with $13.6 \%$ of the high BMI with CO group. The difference remained significant for females where $29.1 \%$ of the normal BMI without CO group were physically active compared with $12.3 \%$ of the high BMI with CO group. Although not statistically significant, the prevalence of frailty was highest in the normal BMI with CO group (9.8\%) followed by high BMI with CO (6.4\%), high BMI without CO (4.3\%), and normal BMI without CO group (3.5\%). The indices for falls were also highest in the normal BMI with CO group (15.7\%), and lowest in the high BMI without CO group (8.6\%). There was a significantly higher prevalence of risk of malnutrition in the normal BMI without CO group (5.7\%) compared with the high BMI with $\mathrm{CO}(2.0 \%)$ and normal BMI with CO groups (2.0\%).

Mean TUG was significantly longer in the high BMI with CO group (11.8 $\pm 3.8 \mathrm{~s})$, and shortest in the high BMI without CO group (10.4 \pm 2.9 s). However, there were gender differences where in male, TUG was longest in the normal BMI with CO group $(12.7 \pm 5.2 \mathrm{~s})$ and shortest in the high BMI without CO group (10.2 \pm 2.8 s) (Supplementary Table 1). In females, TUG was longest in the high BMI with CO group $(12.1 \pm 4.1 \mathrm{~s})$ and shortest in the normal BMI without CO group (10.4 $\pm 5.0 \mathrm{~s})$. With both genders combined, HGS was lowest in the normal BMI with CO group $(19.9 \pm 5.8 \mathrm{~kg})$ and highest in the high BMI without CO group $(26.5 \pm 6.8 \mathrm{~kg})$.
Relative HGS was significantly lower in the high BMI with $\mathrm{CO}$ and normal BMI with $\mathrm{CO}$ group, compared with high $\mathrm{BMI}$ without $\mathrm{CO}$ and normal BMI without $\mathrm{CO}$ group, $0.32 \pm 0.08 \mathrm{~kg}, 0.36 \pm 0.09 \mathrm{~kg}, 0.43 \pm 0.09 \mathrm{~kg}$, and $0.44 \pm 0.10 \mathrm{~kg}$, respectively. For females, there was no significant difference in the HGS between the groups. Both the high BMI with $\mathrm{CO}$ and normal BMI with $\mathrm{CO}$ groups had significantly lower MMSE scores compared with high BMI without $\mathrm{CO}$ and normal BMI without $\mathrm{CO}$ groups, $26.7 \pm 3.0,26.6 \pm 3.6,27.5 \pm 3.0$, and $27.4 \pm 2.9$, respectively.

Tables 2, 3, 4 and 5 summarises the unadjusted and adjusted models of grip strength, relative grip strength, TUG, and MMSE.

Unadjusted, males in high BMI without $\mathrm{CO}$ group had higher HGS compared with the normal BMI without $\mathrm{CO}$ group (B 2.35, 95\% CI 0.49 to $4.21, P=0.01$ ) (Table 2). After adjusting for age, education, height, physical activity, and hypertension, males in the normal BMI with $\mathrm{CO}$ group had lower HGS than those in the normal BMI without CO group (B -3.28, 95\% CI -6.32 to $-0.23, P=0.04$ ). After adjustment, both males and females in the high BMI with $\mathrm{CO}$ and normal $\mathrm{BMI}$ with $\mathrm{CO}$ groups had lower relative HGS; male high BMI with CO (B -0.11, 95\% CI -0.13 to $-0.09, P<0.01$ ), male normal BMI with CO (B -0.10, 95\% CI -0.15 to $-0.05, P<0.01$ ), female high BMI with $\mathrm{CO}$ (B $-0.09,95 \% \mathrm{CI}-0.10$ to $-0.07, P<0.01)$ and female normal BMI with CO (B $-0.03,95 \%$ CI -0.06 to $0.00, P=0.09$ (Table 3). Adjusted relative HGS amongst males in the high BMI without CO group was significantly lower (B -0.04 , $95 \%$ CI -0.07 to $-0.01, P<0.01)$ than those with normal $\mathrm{BMI}$ without $\mathrm{CO}$.

After adjustment, males in the normal BMI with $\mathrm{CO}$ and high BMI with CO group had significantly longer TUG time (B 2.65, 95\% CI 0.45 to $4.84, P=0.02$ ) and (B 1.07, $95 \%$ CI 0.25 to $1.88, P=0.01$ ) respectively compared with the normal BMI without CO group (Table 4). Similarly, MMSE

Table 2 Unadjusted and adjusted B-coefficients, with 95\% Cl, of grip strength in BMI groups with/without central obesity, by gender.

\begin{tabular}{|c|c|c|}
\hline & \multicolumn{2}{|c|}{ Normal BMI } \\
\hline & $\begin{array}{c}\text { No central obesity } \\
\text { (normal BMI without CO) }\end{array}$ & $\begin{array}{c}\text { Central obesity } \\
\text { (normal BMI with CO) }\end{array}$ \\
\hline Males, unadjusted & 0 (Reference) & $\begin{array}{l}-1.99(-5.43 \text { to } 1.46) \\
P=0.26\end{array}$ \\
\hline Males, adjusted & 0 (Reference) & $\begin{array}{l}-3.28(-6.32 \text { to }-0.23) \\
P=0.04\end{array}$ \\
\hline Females, unadjusted & 0 (Reference) & $\begin{array}{l}0.09(-1.54 \text { to } 1.72) \\
P=0.92\end{array}$ \\
\hline Females, adjusted & 0 (Reference) & $\begin{array}{l}0.05(-1.52 \text { to } 1.62) \\
P=0.95\end{array}$ \\
\hline
\end{tabular}

\begin{tabular}{|c|c|}
\hline \multicolumn{2}{|c|}{ High BMI } \\
\hline $\begin{array}{c}\text { No central obesity } \\
\text { (high BMI without CO) }\end{array}$ & $\begin{array}{c}\text { Central obesity } \\
\text { (high BMI with CO) }\end{array}$ \\
\hline $\begin{array}{l}2.35(0.49 \text { to } 4.21) \\
P=0.01\end{array}$ & $\begin{array}{l}0.61(-0.78 \text { to } 2.00) \\
P=0.39\end{array}$ \\
\hline $\begin{array}{l}1.74(-0.01 \text { to } 3.49) \\
P=0.05\end{array}$ & $\begin{array}{l}0.12(-1.30 \text { to } 1.54) \\
P=0.87\end{array}$ \\
\hline $\begin{array}{l}0.44(-1.55 \text { to } 2.42) \\
P=0.67\end{array}$ & $\begin{array}{l}-0.03(-0.96 \text { to } 0.90) \\
P=0.95\end{array}$ \\
\hline $\begin{array}{l}1.48(-0.31 \text { to } 3.28) \\
P=0.10\end{array}$ & $\begin{array}{l}0.19(-0.70 \text { to } 1.09) \\
P=0.67\end{array}$ \\
\hline
\end{tabular}

Bold indicates significance; Adjusted for age, education, height, physical activity, and hypertension $\mathrm{CO}$, central obesity; Reference group, normal BMI without CO.

https://ec.bioscientifica.com https://doi.org/10.1530/EC-21-0223 (c) 2021 The authors Published by Bioscientifica Ltd

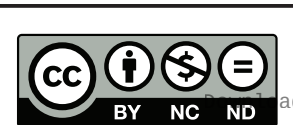

This work is licensed under a Creative Commons Attribution-NonCommercial-NoDerivatives 4.0 Internationabd ficense ifica . com at $04 / 26 / 2023 \quad 08: 20: 23 \mathrm{AM}$ 
Table 3 Unadjusted and adjusted B-coefficients, with $95 \% \mathrm{Cl}$, of relative grip strength in BMI groups with/without central obesity, by gender.

\begin{tabular}{|c|c|c|}
\hline & \multicolumn{2}{|c|}{ Normal BMI } \\
\hline & $\begin{array}{c}\text { No central obesity } \\
\text { (normal BMI without CO) }\end{array}$ & $\begin{array}{c}\text { Central obesity } \\
\text { (normal BMI with CO) }\end{array}$ \\
\hline Males, unadjusted & 0 (Reference) & $\begin{array}{l}-0.09(-0.14 \text { to }-0.03) \\
P<0.01\end{array}$ \\
\hline Males, adjusted & 0 (Reference) & $\begin{array}{l}-0.10(-0.15 \text { to }-0.05) \\
P<0.01\end{array}$ \\
\hline Females, unadjusted & 0 (Reference) & $\begin{array}{l}-0.04(-0.07 \text { to } 0.00) \\
P=0.03\end{array}$ \\
\hline Females, adjusted & 0 (Reference) & $\begin{array}{l}-0.03(-0.06 \text { to } 0.00) \\
P=0.09\end{array}$ \\
\hline
\end{tabular}

\begin{tabular}{|c|c|}
\hline \multicolumn{2}{|c|}{ High BMI } \\
\hline $\begin{array}{c}\text { No central obesity } \\
\text { (high BMI without CO) }\end{array}$ & $\begin{array}{c}\text { Central obesity } \\
\text { (high BMI with CO) }\end{array}$ \\
\hline $\begin{array}{l}-0.02(-0.06 \text { to } 0.01) \\
P=0.11\end{array}$ & $\begin{array}{l}-0.11(-0.13 \text { to }-0.09) \\
P<0.01\end{array}$ \\
\hline $\begin{array}{l}-0.04(-0.07 \text { to }-0.01) \\
P=0.01\end{array}$ & $\begin{array}{l}-0.11(-0.13 \text { to }-0.09) \\
P<0.01\end{array}$ \\
\hline $\begin{array}{l}-0.05(-0.09 \text { to }-0.01) \\
P=0.01\end{array}$ & $\begin{array}{l}-0.09(-0.11 \text { to }-0.07) \\
P<0.01\end{array}$ \\
\hline $\begin{array}{l}-0.04(-0.08 \text { to } 0.00) \\
P=0.06\end{array}$ & $\begin{array}{l}-0.09(-0.10 \text { to }-0.07) \\
P<0.01\end{array}$ \\
\hline
\end{tabular}

Bold indicates significance; Adjusted for age, education, height, physical activity and hypertension. $\mathrm{CO}$, central obesity; Reference group, normal BMI without CO.

scores were generally lower in the presence of $\mathrm{CO}$ in both genders. After adjustment, significance was observed only in males with normal BMI and CO (B -1.60, 95\% CI -3.15 to $-0.06, P=0.04)$.

\section{Discussion}

The prevalence of CO in our older adults was $60.4 \%$, which is similar to other studies ranging from 62 to $65.1 \%$ (26). Slightly more than half had both high BMI and CO. CO in isolation or in combination with high BMI was associated with lower cognitive scores, lower HGS and relative HGS, and longer TUG. There were gender differences in the overall prevalence and associations. Amongst females, $61.0 \%$ belonged to the high BMI with CO group compared with $44.6 \%$ of males, and $4.6 \%$ to the high BMI without CO group compared with $15.0 \%$ of males. Interestingly, males in the high BMI without CO group performed better on the functional and cognitive test, with the lowest performance in the normal BMI with CO group. In females, there were no significant differences in the cognitive scores and HGS between groups except TUG being longest in the high BMI with CO group and shortest in the normal BMI without CO group, and lower relative HGS in the high BMI with $\mathrm{CO}$, high BMI without $\mathrm{CO}$ and normal BMI with $\mathrm{CO}$ groups.

There was a higher prevalence of CO in older adults with high BMI in our participants. Adipose tissue is proinflammatory, and aging is also associated with low-grade inflammation with an increase in visceral adipose tissue, ectopic fat distribution, and redistribution of body fat (27). $\mathrm{CO}$, through its 'inflammaging' effect, is associated with disability and mortality. It is associated with lower lung function, and in a most recent study, abdominal obesity measured by increased waist-hip ratio and not metabolic syndrome was associated with increased respiratory deterioration in COVID-19 (28, 29). WC and abdominal obesity are also associated with vertebral fracture risk (30). While in younger adults high BMI is associated with increased morbidity and mortality, mortality was higher in older adults with a lower range of recommended BMI and lower in those with higher BMI $(4,31)$. High BMI between 25.0 and $34.9 \mathrm{~kg} / \mathrm{m}^{2}$ has also been shown to be associated with lower mortality in frail older women (32).

Table 4 Unadjusted and adjusted B-coefficients, with 95\% Cl, of TUG in BMI groups with/without central obesity, by gender.

\begin{tabular}{|c|c|c|}
\hline & \multicolumn{2}{|c|}{ Normal BMI } \\
\hline & $\begin{array}{c}\text { No central obesity } \\
\text { (normal BMI without CO) }\end{array}$ & $\begin{array}{c}\text { Central obesity } \\
\text { (normal BMI with CO) }\end{array}$ \\
\hline Males, unadjusted & 0 (Reference) & $\begin{array}{l}1.80(-0.75 \text { to } 4.35) \\
P=0.16\end{array}$ \\
\hline Males, adjusted & 0 (Reference) & $\begin{array}{l}2.65(0.45 \text { to } 4.84) \\
P=0.02\end{array}$ \\
\hline Females, unadjusted & 0 (Reference) & $\begin{array}{l}0.23(-1.45 \text { to } 1.91) \\
P=0.79\end{array}$ \\
\hline Females, adjusted & 0 (Reference) & $\begin{array}{l}-0.71(-2.37 \text { to } 0.96) \\
P=0.40\end{array}$ \\
\hline
\end{tabular}

\begin{tabular}{|c|c|}
\hline \multicolumn{2}{|c|}{ High BMI } \\
\hline $\begin{array}{c}\text { No central obesity } \\
\text { (high BMI without CO) }\end{array}$ & $\begin{array}{c}\text { Central obesity } \\
\text { (high BMI with CO) }\end{array}$ \\
\hline $\begin{array}{l}-0.69(-1.94 \text { to } 0.57) \\
P=0.28\end{array}$ & $\begin{array}{l}0.55(-0.30 \text { to } 1.39) \\
P=0.21\end{array}$ \\
\hline $\begin{array}{l}0.27(-0.95 \text { to } 1.48) \\
P=0.66\end{array}$ & $\begin{array}{l}1.07(0.25 \text { to } 1.88) \\
P=0.01\end{array}$ \\
\hline $\begin{array}{l}0.62(-1.73 \text { to } 2.97) \\
P=0.60\end{array}$ & $\begin{array}{l}1.68(0.66 \text { to } 2.69) \\
P<0.01\end{array}$ \\
\hline $\begin{array}{l}0.19(-2.14 \text { to } 2.53) \\
P=0.87\end{array}$ & $\begin{array}{l}0.90(-0.06 \text { to } 1.85) \\
P=0.07\end{array}$ \\
\hline
\end{tabular}

Bold indicates significance; Adjusted for age, education, height, physical activity and hypertension. CO, central obesity; Reference group, normal BMI without CO; TUG, timed up and go.

https://ec.bioscientifica.com https://doi.org/10.1530/EC-21-0223 (c) 2021 The authors Published by Bioscientifica Ltd

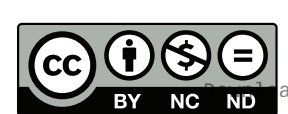

This work is licensed under a Creative Commons Attribution-NonCommercial-NoDerivatives 4.0 International License.ifica com at 04/26/2023 08:20:23AM 
Table 5 Unadjusted and adjusted B-coefficients, with 95\% Cl, of MMSE Score in BMI groups with/without central obesity, by gender.

\begin{tabular}{|c|c|c|}
\hline & \multicolumn{2}{|c|}{ Normal BMI } \\
\hline & $\begin{array}{c}\text { No central obesity } \\
\text { (normal BMI without CO) }\end{array}$ & $\begin{array}{c}\text { Central obesity } \\
\text { (normal BMI with CO) }\end{array}$ \\
\hline Males, unadjusted & 0 (Reference) & $\begin{array}{l}-1.08(-2.66 \text { to } 0.49) \\
P=0.18\end{array}$ \\
\hline Males, adjusted & 0 (Reference) & $\begin{array}{l}-1.60(-3.15 \text { to }-0.06) \\
P=0.04\end{array}$ \\
\hline Females, unadjusted & 0 (Reference) & $\begin{array}{l}-0.28(-1.54 \text { to } 0.97) \\
P=0.65\end{array}$ \\
\hline Females, adjusted & 0 (Reference) & $\begin{array}{l}0.09(-1.08 \text { to } 1.26) \\
P=0.88\end{array}$ \\
\hline
\end{tabular}

\begin{tabular}{|c|c|}
\hline \multicolumn{2}{|c|}{ High BMI } \\
\hline $\begin{array}{c}\text { No central obesity } \\
\text { (high BMI without CO) }\end{array}$ & $\begin{array}{c}\text { Central obesity } \\
\text { (high BMI with CO) }\end{array}$ \\
\hline $\begin{array}{l}0.07(-0.71 \text { to } 0.85) \\
P=0.86\end{array}$ & $\begin{array}{l}-0.10(-0.62 \text { to } 0.43) \\
P=0.72\end{array}$ \\
\hline $\begin{array}{l}-0.06(-0.87 \text { to } 0.75) \\
P=0.88\end{array}$ & $\begin{array}{l}-0.31(-0.86 \text { to } 0.24) \\
P=0.26\end{array}$ \\
\hline $\begin{array}{l}-0.61(-2.34 \text { to } 1.12) \\
P=0.49\end{array}$ & $\begin{array}{l}-0.79(-1.55 \text { to }-0.03) \\
P=0.04\end{array}$ \\
\hline $\begin{array}{l}-0.03(-1.61 \text { to } 1.55) \\
P=0.97\end{array}$ & $\begin{array}{l}-0.14(-0.84 \text { to } 0.56) \\
P=0.69\end{array}$ \\
\hline
\end{tabular}

Bold indicates significance; Adjusted for age, education, height, physical activity and hypertension. CO, central obesity; MMSE, mini mental state examination; Reference group, normal BMI without CO.

The association of HGS in metabolic syndrome and obesity is an evolving area of research where recent studies suggest that relative HGS measured by either HGS/BMI or HGS/body weight may better predict negative outcomes in obese older adults (15). Male in the high BMI without CO group had significantly higher HGS than the normal BMI without $\mathrm{CO}$ group but was no longer significant after adjusting for confounding factors. However, males in the normal BMI with $\mathrm{CO}$ group had significantly lower HGS even after adjustment which further supports the role of 'inflammaging' and intramuscular fat distribution affecting muscle quality (33). Relative HGS may be an early marker of muscle quality and was low in the high BMI with $\mathrm{CO}$ and normal BMI with $\mathrm{CO}$ groups.

The high BMI without CO group in our study, especially males, had higher HGS and shorter TUG compared with the normal BMI with $\mathrm{CO}$ and high BMI with $\mathrm{CO}$ group. High BMI in older adults has been associated with increased survival and better cognitive scores $(4,5)$. The high BMI without CO group in our study also had higher MMSE scores, which has also been shown in previous studies. CO is reflective of visceral fat and is associated with increased mortality and lower cognitive scores (5, $32,34)$. Previous studies have shown that those with CO and high BMI are at increased risk of cognitive impairment (35). In our study, both the normal BMI with $\mathrm{CO}$ and high BMI with CO groups had lower cognitive scores. In the multivariate model, the male normal BMI with CO group had significantly lower MMSE compared with the normal $\mathrm{BMI}$ without $\mathrm{CO}$ group. If $\mathrm{BMI}$ is used as the only measure for obesity, $6.8 \%$ of the population with $\mathrm{CO}$ and normal BMI would have been excluded from any interventions and our study has shown that this group is at high risk of negative outcomes.

Being overweight in older adults may reflect better nutritional status whereas weight loss is associated with frailty and increased mortality $(31,32)$. The normal BMI without $\mathrm{CO}$ group had about 2.5 times higher risk of malnutrition compared with the normal BMI with $\mathrm{CO}$ or high BMI with CO groups, and 5.7 times compared with the high BMI without CO group. Frailty prevalence in the normal BMI with CO group was almost three times higher than that of the normal BMI without $\mathrm{CO}$ and double compared with the high BMI without CO group. Many studies, including a recent study by Alfonso et al., showed that frailty is highly associated with 'general and abdominal obesity' where general obesity was defined as BMI $\geq 30.0$ $\mathrm{kg} / \mathrm{m}^{2}$ (36). The same group also had low HGS (37). Our study also revealed similar findings where the normal BMI with CO group had the highest frailty prevalence and the high BMI without CO group had the highest HGS.

Our study showed a significant negative association of CO with muscle strength as reflected by lower HGS, whereas high BMI without $\mathrm{CO}$ showed a significant positive association, especially in males. The high BMI with $\mathrm{CO}$ and normal BMI with $\mathrm{CO}$ population in our study did have longer TUG, and higher prevalence of falls. In some studies, obesity is associated with higher muscle mass but poor muscle quality and function due to intramuscular fat infiltration affecting muscle strength leading to frailty, sarcopenia, increased mortality, and morbidity (38). 'Sarcopenic obesity', defined by the concurrent presence of obesity with low muscle mass and function, has been an emerging area of research in recent years where the discussion on definition, diagnostic criteria, and management continues to evolve (39). Gain in visceral fat as reflected by $\mathrm{CO}$ has been associated with increased fracture risk and functional decline (40). Concurrent presence of obesity, sarcopenia, osteoporosis, and frailty can accelerate the functional decline, and interventions need to address all the factors together (41). Weight reduction without protein supplementation and https://ec.bioscientifica.com https://doi.org/10.1530/EC-21-0223 (c) 2021 The authors Published by Bioscientifica Ltd
This work is licensed under a Creative Commons Attribution-NonCommercial-NoDerivatives 4.0 International License.ifica com at $04 / 26 / 2023$ 08:20:23AM 
resistance exercise can compromise the ability to maintain muscle mass and function leading to frailty, sarcopenia, and increased mortality $(39,42,43)$. Skeletal muscle assessment and maintenance should be an integral part of all obesity clinics. Obesity has been linked to poor physical function and ADL impairment.

There was a higher prevalence of diabetes in the high BMI with $\mathrm{CO}$ group followed by normal BMI with $\mathrm{CO}$ and high BMI without $\mathrm{CO}$ groups. Previous studies have shown that BMI, CO, and high waist hip ratio (WHR) are all associated with diabetes (44). Interestingly, body shape index and WHR, and not high BMI, are associated with a higher incidence of stroke in diabetics (45). The prevalence of strokes was highest in our high BMI with CO group.

Our study includes population-level data from an Asian country and has shown that $\mathrm{CO}$ reflected by high WC is associated with negative functional and cognitive outcomes across genders. High BMI in the absence of $\mathrm{CO}$ may be associated with better outcomes, especially in males. This has further reinforced the need to measure WC in older adults. WC may be a better measure of obesity and is associated with many negative consequences including cognitive and functional impairment, and cardiometabolic diseases. BMI alone in older adults may not be a good reflection of obesity as losing height may over-estimate the BMI, although $85 \%$ of our population with high BMI had CO. High WC and BMI in combination may be a better prediction of obesity-related morbidity and mortality (37). WC is currently not routinely measured due to technical difficulties, but findings from our study and previous studies have highlighted that WC should be included as one of the vital signs measured in primary care, with necessary interventions put in place to screen for chronic diseases, function, frailty, and cognitive outcomes. Physical activity has been shown to reduce mortality in those with high adiposity $(46,47)$.

Our study has several limitations which warrant mention. We only looked at BMI and WC, but not WHR as indicator of obesity and association with negative outcomes. WHR is known to be associated with an increased cardiovascular mortality and diabetes, but its impact on cognition and function is still an evolving area of research $(7,45,48)$. Risk of cognitive impairment has been shown to be higher in older adults with high WHR and BMI $>25.3 \mathrm{~kg} / \mathrm{m}^{2}$ (35). While we included education status where the high BMI without $\mathrm{CO}$ group was better educated than the normal BMI with CO group, we did not include or adjust for socio-economic status. Many studies have found that general obesity defined by BMI $\geq 30.0 \mathrm{~kg} / \mathrm{m}^{2}$ is associated with negative outcomes including mortality, frailty, and decline in walking speed $(10,49)$. However, we defined high BMI as $\geq 23.0 \mathrm{~kg} / \mathrm{m}^{2}$ and did not further stratify into overweight and obese groups due to the small sample size. While our study is representative of community-dwelling older adults, the sample size in both the high BMI without $\mathrm{CO}$ and normal BMI with $\mathrm{CO}$ group is relatively small. While there were significant associations with negative outcomes, it needs to be further validated with a larger sample size. In addition, self-reporting may lead to under-reporting and recall bias.

With the globally aging population and effect of the COVID-19 pandemic, the prevalence of older adults with obesity will increase. Public education should focus on measuring WC and CO rather than BMI alone in older adults, with increased emphasis on frailty and sarcopenia prevention. Further longitudinal studies are needed to validate the benefits of high BMI both in male and female and to determine the optimal cut-off for WC and BMI in predicting adverse outcomes in older adults with heterogenous functional status, across different populations and ethnicity worldwide. In addition, the impact of reducing WC on cognition and physical function needs to be further evaluated in older adults.

\section{Conclusion}

CO may be a better reflection of obesity and predictor of adverse outcomes in older adults. High BMI without CO was associated with better functional and cognitive outcomes especially in males but requires further validation. Public education should focus not on reducing weight but rather on reducing WC and building muscle strength as weight loss is associated with frailty. More prospective longitudinal studies are needed on the impact of BMI, CO alone, or in combination on intrinsic capacity, morbidity, and mortality.

\section{Supplementary materials}

This is linked to the online version of the paper at https://doi.org/10.1530/ EC-21-0223.

\section{Declaration of interest}

The authors declare that there is no conflict of interest that could be perceived as prejudicing the impartiality of the research.

\section{Funding}

This work was funded by $\mathrm{Dr}$ Oon Chiew Seng, National University of Singapore. (c) 2021 The authors Published by Bioscientifica Ltd
This work is licensed under a Creative Commons Attribution-NonCommercial-NoDerivatives 4.0 Internationad ticense.ifica.com at 04/26/2023 08:20:23AM 


\section{Acknowledgement}

The authors thank the Saw Swee Hock School of Public Health, National University of Singapore, for their collaboration.

\section{References}

1 Ng M, Fleming T, Robinson M, Thomson B, Graetz N, Margono C, Mullany EC, Biryukov S, Abbafati C, Abera SF, et al. Global, regional, and national prevalence of overweight and obesity in children and adults during 1980-2013: a systematic analysis for the Global Burden of Disease Study 2013. Lancet 2014384 766-781. (https://doi. org/10.1016/S0140-6736(14)60460-8)

2 Lang IA, Llewellyn DJ, Alexander K \& Melzer D. Obesity, physical function, and mortality in older adults. Journal of the American Geriatrics Society 200856 1474-1478. (https://doi.org/10.1111/j.15325415.2008.01813.x)

3 Andreacchi AT, Griffith LE, Guindon GE, Mayhew A, Bassim C, Pigeyre M, Stranges S \& Anderson LN. Body mass index, waist circumference, waist-to-hip ratio, and body fat in relation to health care use in the Canadian Longitudinal Study on Aging. International Journal of Obesity 202145 666-676. (https://doi.org/10.1038/s41366-020-00731-z)

4 Stessman J, Jacobs JM, Ein-Mor E \& Bursztyn M. Normal body mass index rather than obesity predicts greater mortality in elderly people: the Jerusalem Longitudinal Study. Journal of the American Geriatrics Society 200957 2232-2238. (https://doi.org/10.1111/j.15325415.2009.02567.x)

5 West NA, Lirette ST, Cannon VA, Turner ST, Mosley Jr TH \& Windham BG. Adiposity, change in adiposity, and cognitive decline in mid- and late life. Journal of the American Geriatrics Society $2017 \mathbf{6 5}$ 1282-1288. (https://doi.org/10.1111/jgs.14786)

6 Hou Q, Guan Y, Yu W, Liu X, Wu L, Xiao M \& Lü Y. Associations between obesity and cognitive impairment in the Chinese elderly: an observational study. Clinical Interventions in Aging 201914 367-373. (https://doi.org/10.2147/CIA.S192050)

7 Czernichow S, Kengne AP, Stamatakis E, Hamer M \& Batty GD. Body mass index, waist circumference and waist-hip ratio: which is the better discriminator of cardiovascular disease mortality risk? Evidence from an individual-participant meta-analysis of 82864 participants from nine cohort studies. Obesity Reviews 201112 680-687. (https:// doi.org/10.1111/j.1467-789X.2011.00879.x)

8 Wang Y, Beydoun MA, Min J, Xue H, Kaminsky LA \& Cheskin LJ. Has the prevalence of overweight, obesity and central obesity levelled off in the United States? Trends, patterns, disparities, and future projections for the obesity epidemic. International Journal of Epidemiology 202049 810-823. (https://doi.org/10.1093/ije/dyz273)

9 Walls HL, Stevenson CE, Mannan HR, Abdullah A, Reid CM, McNeil JJ \& Peeters A. Comparing trends in BMI and waist circumference. Obesity 201119 216-219. (https://doi.org/10.1038/ oby.2010.149)

10 Flegal KM, Graubard BI, Williamson DF \& Gail MH. Excess deaths associated with underweight, overweight, and obesity. JAMA 2005293 1861-1867. (https://doi.org/10.1001/jama.293.15.1861)

11 Bender R, Jöckel KH, Trautner C, Spraul M \& Berger M. Effect of age on excess mortality in obesity. JAMA 1999281 1498-1504. (https://doi. org/10.1001/jama.281.16.1498)

12 Chang YH, Yang HY \& Shun SC. Effect of exercise intervention dosage on reducing visceral adipose tissue: a systematic review and network meta-analysis of randomized controlled trials. International Journal of Obesity 202145 982-997. (https://doi.org/10.1038/s41366021-00767-9)

13 Yoshimoto K, Noda T \& Imamura T. Influence of underlying diseases and age on the association between obesity and all-cause mortality in post-middle age. Health 201810 14. (https://doi.org/10.4236/ health.2018.109089)

14 Merchant RA, Chen MZ, Tan LWL, Lim MY, Ho HK \& van Dam RM. Singapore healthy older people everyday (HOPE) study: prevalence of frailty and associated factors in older adults. Journal of the American Medical Directors Association 201718 734.e9-734.e14. (https://doi. org/10.1016/j.jamda.2017.04.020)

15 Merchant RA, Chan YH, Lim JY \& Morley JE. Prevalence of metabolic syndrome and association with grip strength in older adults: findings from the HOPE study. Diabetes, Metabolic Syndrome and Obesity: Targets and Therapy 202013 2677-2686. (https://doi.org/10.2147/DMSO. S260544)

16 Lim SL, Tong CY, Ang E, Lee EJ-C, Loke WC, Chen Y, Ferguson M \& Daniels L. Development and validation of 3-minute nutrition screening (3-MinNS) tool for acute hospital patients in Singapore. Asia Pacific Journal of Clinical Nutrition 200918 395-403. (https://doi. org/10.6133/APJCN.2009.18.3.12)

17 Yang YJ. An overview of current physical activity recommendations in primary care. Korean Journal of Family Medicine 201940 135-142. (https://doi.org/10.4082/kjfm.19.0038)

18 Lawton MP \& Brody EM. Assessment of older people: self-maintaining and instrumental activities of daily living. Gerontologist 19699 179-186. (https://doi.org/10.1093/geront/9.3_Part_1.179)

19 Mahoney FI \& Barthel DW. Functional evaluation: the Barthel index. Maryland State Medical Journal 196514 61-65.

20 Folstein MF, Folstein SE \& McHugh PR. 'Mini-mental state'. A practical method for grading the cognitive state of patients for the clinician. Journal of Psychiatric Research 197512 189-198. (https://doi. org/10.1016/0022-3956(75)90026-6)

21 Woo J, Yu R, Wong M, Yeung F, Wong M \& Lum C. Frailty screening in the community using the FRAIL scale. Journal of the American Medical Directors Association 201516 412-419. (https://doi.org/10.1016/j. jamda.2015.01.087)

22 Herdman M, Gudex C, Lloyd A, Janssen M, Kind P, Parkin D, Bonsel G $\&$ Badia X. Development and preliminary testing of the new fivelevel version of EQ-5D (EQ-5D-5L). Quality of Life Research 201120 1727-1736. (https://doi.org/10.1007/s11136-011-9903-x)

23 Podsiadlo D \& Richardson S. The timed 'Up and Go': a test of basic functional mobility for frail elderly persons. Journal of the American Geriatrics Society 199139 142-148. (https://doi. org/10.1111/j.1532-5415.1991.tb01616.x)

24 WHO Expert Consultation. Appropriate body-mass index for Asian populations and its implications for policy and intervention strategies. Lancet 2004363 157-163. (https://doi.org/10.1016/S01406736(03)15268-3)

25 Alberti KG, Zimmet P \& Shaw J. Metabolic syndrome - a new worldwide definition. A consensus statement from the International Diabetes Federation. Diabetic Medicine 200623 469-480. (https://doi. org/10.1111/j.1464-5491.2006.01858.x)

26 Cho BY, Seo DC, Lin HC, Lohrmann DK \& Chomistek AK. BMI and central obesity with falls among community-dwelling older adults. American Journal of Preventive Medicine 201854 e59-e66. (https://doi. org/10.1016/j.amepre.2017.12.020)

27 Zamboni M, Nori N, Brunelli A \& Zoico E. How does adipose tissue contribute to inflammageing? Experimental Gerontology 2021143 111162. (https://doi.org/10.1016/j.exger.2020.111162)

28 Svartengren M, Cai GH, Malinovschi A, Theorell-Haglöw J, Janson C, Elmståhl S, Lind L, Lampa E \& Lindberg E. The impact of body mass index, central obesity and physical activity on lung function: results of the EpiHealth study. ERJ Open Research 20206 00214-2020. (https:// doi.org/10.1183/23120541.00214-2020)

29 van Zelst CM, Janssen ML, Pouw N, Birnie E, Castro Cabezas M \& Braunstahl GJ. Analyses of abdominal adiposity and metabolic syndrome as risk factors for respiratory distress in COVID-19. BMJ Open Respiratory Research 20207 e000792. (https://doi.org/10.1136/bmjresp-2020-000792) https://ec.bioscientifica.com https://doi.org/10.1530/EC-21-0223 (c) 2021 The authors Published by Bioscientifica Ltd
This work is licensed under a Creative Commons Attribution-NonCommercial-NoDerivatives 4.0 International License.ifica com at 04/26/2023 08:20:23AM 
30 Kim W, Nam GE, Han K, Jung JH, Lee J, Park CM, Kim YH, Kim JH, Kim SM, Park YG, et al. Impact of waist circumference on the risk of vertebral fracture: a nationwide cohort study in South Korea. Bone 2021145 115870. (https://doi.org/10.1016/j. bone.2021.115870)

31 Winter JE, MacInnis RJ, Wattanapenpaiboon N \& Nowson CA. BMI and all-cause mortality in older adults: a meta-analysis. American Journal of Clinical Nutrition 201499 875-890. (https://doi.org/10.3945/ ajcn.113.068122)

32 Zaslavsky O, Rillamas-Sun E, LaCroix AZ, Woods NF, Tinker LF, Zisberg A, Shadmi E, Cochrane B, Edward BJ, Kritchevsky S, et al. Association Between anthropometric measures and long-term survival in frail older women: observations from the Women's Health Initiative study. Journal of the American Geriatrics Society 201664 277-284. (https://doi.org/10.1111/jgs.13930)

33 Nelke C, Dziewas R, Minnerup J, Meuth SG \& Ruck T. Skeletal muscle as potential central link between sarcopenia and immune senescence. EBiomedicine 201949 381-388. (https://doi.org/10.1016/j. ebiom.2019.10.034)

34 Cho GJ, Yoo HJ, Hwang SY, Choi J, Lee KM, Choi KM, Baik SH, Han SW \& Kim T. Differential relationship between waist circumference and mortality according to age, sex, and body mass index in Koreans with age of 30-90 years; a nationwide health insurance database study. BMC Medicine 201816 131. (https://doi. org/10.1186/s12916-018-1114-7)

35 Zhang T, Yan R, Chen Q, Ying X, Zhai Y, Li F, Wang X, He F, Ye C \& Lin J. Body mass index, waist-to-hip ratio and cognitive function among Chinese elderly: a cross-sectional study. BMJ Open $2018 \mathbf{8}$ e022055. (https://doi.org/10.1136/bmjopen-2018-022055)

36 García-Esquinas E, José García-García F, León-Muñoz LM, Carnicero JA, Guallar-Castillón P, Gonzalez-Colaço Harmand M, López-García E, Alonso-Bouzón C, Rodríguez-Mañas L \& RodríguezArtalejo F. Obesity, fat distribution, and risk of frailty in two population-based cohorts of older adults in Spain. Obesity 201523 847-855. (https://doi.org/10.1002/oby.21013)

37 Afonso C, Sousa-Santos AR, Santos A, Borges N, Padrão P, Moreira P $\&$ Amaral TF. Frailty status is related to general and abdominal obesity in older adults. Nutrition Research 202185 21-30. (https://doi. org/10.1016/j.nutres.2020.10.009)

38 An KO \& Kim J. Association of sarcopenia and obesity with multimorbidity in Korean adults: a nationwide cross-sectional study. Journal of the American Medical Directors Association 201617960. e1-960.e7. (https://doi.org/10.1016/j.jamda.2016.07.005)

39 Barazzoni R, Bischoff S, Boirie Y, Busetto L, Cederholm T, Dicker D, Toplak H, Van Gossum A, Yumuk V \& Vettor R. Sarcopenic obesity: time to meet the challenge. Obesity Facts 201811 294-305. (https:// doi.org/10.1159/000490361)
40 Lang T, Cauley JA, Tylavsky F, Bauer D, Cummings S, Harris TB \& Health ABC Study. Computed tomographic measurements of thigh muscle cross-sectional area and attenuation coefficient predict hip fracture: the health, aging, and body composition study. Journal of Bone and Mineral Research 201025 513-519. (https://doi.org/10.1359/jbmr.090807)

41 Kirk B, Feehan J, Lombardi G \& Duque G. Muscle, bone, and fat crosstalk: the biological role of myokines, osteokines, and Adipokines. Current Osteoporosis Reports 202018 388-400. (https://doi.org/10.1007/ s11914-020-00599-y)

42 Hsu KJ, Chien KY, Tsai SC, Tsai YS, Liao YH, Chen JJ, Chen YR \& Chen CN. Effects of exercise alone or in combination with highprotein diet on muscle function, aerobic capacity, and physical function in middle-aged obese adults: a randomized controlled trial. Journal of Nutrition, Health and Aging 202125 727-734. (https://doi. org/10.1007/s12603-021-1599-1)

43 Dent E, Morley JE, Cruz-Jentoft AJ, Arai H, Kritchevsky SB, Guralnik J, Bauer JM, Pahor M, Clark BC, Cesari M, et al. International clinical practice guidelines for sarcopenia (ICFSR): screening, diagnosis and management. Journal of Nutrition, Health and Aging 201822 1148-1161. (https://doi.org/10.1007/s12603-018-1139-9)

44 Vazquez G, Duval S, Jacobs DR, Jr \& Silventoinen K. Comparison of body mass index, waist circumference, and waist/hip ratio in predicting incident diabetes: a meta-analysis. Epidemiologic Reviews 200729 115-128. (https://doi.org/10.1093/epirev/mxm008)

45 Mozafar Saadati H, Mehrabi Y, Sabour S, Mansournia MA \& Hashemi Nazari SS. Estimating the effects of body mass index and central obesity on stroke in diabetics and non-diabetics using targeted maximum likelihood estimation: atherosclerosis risk in communities study. Obesity Science and Practice 20206 628-637. (https://doi. org/10.1002/osp4.447)

46 Sanchez-Lastra MA, Ding D, Dalene KE, Ekelund U \& Tarp J. Physical activity and mortality across levels of adiposity: a prospective cohort study from the UK Biobank. Mayo Clinic Proceedings 202196 105-119. (https://doi.org/10.1016/j.mayocp.2020.06.049)

47 Marconcin P, Ihle A, Werneck AO, Gouveia ER, Ferrari G, Peralta M $\&$ Marques $\mathrm{A}$. The association of healthy lifestyle behaviors with overweight and obesity among older adults from 21 countries. Nutrients 202113 315. (https://doi.org/10.3390/nu13020315)

48 Liu Z, Yang H, Chen S, Cai J \& Huang Z. The association between body mass index, waist circumference, waist-hip ratio and cognitive disorder in older adults. Journal of Public Health 201941 305-312. (https://doi.org/10.1093/pubmed/fdy121)

49 Wennman H, Jerome GJ, Simonsick EM, Sainio P, Valkeinen H, Borodulin K \& Stenholm S. Adiposity markers as predictors of 11-year decline in maximal walking speed in late midlife. Journal of Applied Gerontology 202140 1110-1115. (https://doi. org/10.1177/0733464820911542)

Received in final form 24 June 2021

Accepted 14 July 2021

Accepted Manuscript published online 14 July 2021 https://ec.bioscientifica.com https://doi.org/10.1530/EC-21-0223 (c) 2021 The authors Published by Bioscientifica Ltd
This work is licensed under a Creative Commons Attribution-NonCommercial-NoDerivatives 4.0 International License if $i c a$ com at $04 / 26 / 2023$ 08:20:23AM 